UDK $614.7,613.5$

\title{
INFLUENCE OF RADON PROTECTING MEASURES IN CHILDREN EDUCATIONAL INSTITUTIONS ON THE RADIATION RISK EXPOSURE TO RADON (AN EXAMPLE OF ONE OF THE SCHOOLS IN ST. PETERSBURG)
}

\section{D.V. Kononenko, T.A. Kormanovskaya}

Federal Budget Scientific Institution "St. Petersburg research institute of radiation hygiene named after professor P.V.Ramzaev", Russian Federation, St. Petersburg, 8 Mira St., 197101

\begin{abstract}
The article presents summary information about modern approaches to risk assessment of radoninduced lung cancer caused by exposure to radon of the population and by radon's short-lived daughter decomposition products in residential and public buildings. It is pointed out on the importance of radonprotecting measures in children's school and pre-school institutions. As the example for applying of risk assessment models as an instrument for the effectivness of implemented measures, the results of calculation of lifetime attributable risk before and after radon protection in one of the school of St. Petersburg have been introduced.
\end{abstract}

Key words: radon, lung cancer, model, assessment of radiation risk, lifetime attributable risk, radon-protecting measures.

In the late 1980s, the World Health Organization and the International Agency for Research on Cancer classified radon and its short-lived daughter products of decay (DPR) as a carcinogenic environmental factor for human lungs [13, 17], based on indisputable evidence obtained in experimental studies on laboratory animals and epidemiological studies among uranium miners. In 1999, the National Academy of Sciences released a report «BEIR VI» [11] in which it was concluded that radon in indoor air is the second leading cause of lung cancer after smoking.

By the end of the $20^{\text {th }}$ century, based on the results of epidemiological studies of the groups of uranium and other miners, a number of models was developed for assessing the risk of radon induced lung cancer that, in accordance with the recommendations of Publication 65 (1993) International Commission on Radiological Protection (ICRP) [3, 18] has a multiplicative form (ie, the probability of radon induced cancer depends on the background level of cancer in the population of a given location). However, over the last 20 years, there has been an ongoing debate about the applicability of these models to assess the risk in exposure to radon in homes and public buildings. In early 2000s, the results of several joint epidemiological studies were

${ }^{\odot}$ Kononenko D.V., Kormanovskaya T.A., 2014

Kononenko Dmitry Viktorovich - Junior research assistant (e-mail: belovlas@yandex.ru; tel.: +7(812)232-43-29).

Kormanovskaya Tatyana Anatolievna - Candidate of Biological Sciences, Head of laboratory (e-mail: f4dos@mail.ru; tel.: $+7(812) 232-74-63)$. 
published - on the connection between human indoor radon exposure and lung cancer by the "case-control" method, launched in the late 1980s. [10, 19-22], as well as several joint epidemiological studies among miners with relatively low levels of total exposure [15, 16, 23, $25]$.

These results were carefully analyzed by the Working Group of the ICRP, specially created in 2005. In November 2009, the Commission approved a "Statement on Radon", and in 2010, Publication 115 [7, 12] was released in which it was confirmed that additional absolute risk of lung cancer associated with radon and its DPR calculated for exposure in homes, was comparable with the estimates obtained from the study among the miners at low levels of exposure. In addition, the Publication confirms that the evidence of increased risk for the population irradiated with equivalent equilibrium volume activity (EEVA) of radon is even less than $100 \mathrm{~Bq} / \mathrm{m} 3$, is convincing and conclusive.

During the 12 years of functioning of the Integrated system for the control of and accounting for the exposure doses as well as the formation in 2001 of "The Federal data bank on doses to the population of the Russian Federation at the expense of natural and technological changes in the radiation background", a unique array of information was collected on the levels of radon and its DPR in the air of residential buildings. The geography of these data is very wide and covers almost all regions of the Russian Federation. According to the 2001-2012 data [2], in Russia there are 5 regions in which average annual individual effective doses of public exposure to the natural sources of ionizing radiation are higher (in the range of 5 to $10 \mathrm{mSv} /$ year): the Republic of Altai, the Tyva Republic, Stavropol, Transbaikalia territory, and Jewish AO. At the same time, more than $60 \%$ of the dose is inhaled radon isotopes and DPR. Despite the fact that the average doses in other regions are not elevated, there are population groups for which the radon dose can greatly exceed the average for the region, as well as the geographic areas and neighborhoods characterized by elevated radon. These regions include, among others, St. Petersburg with an average value of radon EEVA in the air of residential buildings in the entire city of about $21 \mathrm{~Bq} / \mathrm{m} 3$ [6], in some areas the value of this index reaches several hundreds or even thousands of $\mathrm{Bq} / \mathrm{m} 3$ that exceeds the norm tenfold. These areas include, for example, Krasnoselsk and Pushkin where the main source of radon in buildings is the underlying rocks with a high content of uranium and radium - Dictyonema shales, with uranium content above background 10-100 times that come to the surface, or located in close proximity to the earth surface [1].

One of these buildings is the State budget educational institution boarding school №289, Krasnoselsk area, Mozhaisk village, in which a significant excess of the norm on radon EEVA 
was detected in 2001. In 2002-2006, several radon-reduction activities were carried out in the buildings, resulting in normalized situation. The Scientific Research Institute of Radiation Hygiene named after Professor P.V. Ramzaev performed measuring of and expert support for all the phases of radon-reduction activities, and developed a plan for the final stage of activities, which made a major contribution to the normalization of the situation.

Materials and methods. In Publication 115, ICRP gives preference to those models for the assessment of the risk of radon induced lung cancer that were based on the joint analytical studies (and not the individual studies), in particular, the Franco-Czech unified model (FCZ). We used this model, the structure of which is described in the literature [15, 24], to estimate the lifetime attributable risk (LAR), which is the proportion of deaths from radon-induced lung cancer. The indicator calculation method is described in several publications, for example [14]. We also took into account the five-year latency period in the development of lung cancer.

The age and sex distribution of the gross mortality from lung cancer of various nature, needed for the calculation, was obtained using the age-sex distribution of the number of deaths from the cancer of this localization and the corresponding distribution of the total population of the city according to the procedure described in the manual [9]. The sources of the original data included the directory "Malignancies in Russia in 2009 (morbidity and mortality)" [4] and the Unified interagency statistical information system (UISIS) [5]. Furthermore, for the calculation of exposure, we used the maximum permissible weekly educational loads in various school classes listed in SanPiN 2.4.2.2821-10 [8].

To calculate the cumulative exposure to radon and its DPR, we considered a situation of continuous lifetime exposure at the city average radon EEVA equal to $20.6 \mathrm{~Bq} / \mathrm{m} 3$ [6], except for 11 years in school when a child spends part of time corresponding to the particular age in a more intense radon atmosphere. The input data for the evaluation of radon EEVA at school before and after the implementation of radon-reduction activities were the results of more than a thousand measurements taken from 2003 to 2012, with the help of instant, quasiintegral and integral methods in all the months of the year, which provides correct estimates of the average annual value of the indicator that has a significant seasonal variability. According to generally accepted in the international scientific community's views [25], the distribution of values of radon EEVA obeys lognormal. Therefore, median is used as an average value. The characteristics of the array of data and parameters of the lognormal distribution are shown in Table. 1. 
Characteristics of the array of data

\begin{tabular}{|l|c|}
\hline \multicolumn{1}{|c|}{ Parameter } & Value \\
\hline \multicolumn{2}{|c|}{ Prior to radon-reduction activities } \\
\hline Number of measurements & 501 \\
\hline Median, $\mathrm{Bq} / \mathrm{m}^{3}$ & 231 \\
\hline Geometric Standard Deviation $\sigma_{g}$ & 2,4 \\
\hline \multicolumn{2}{|c|}{ After radon-reduction activities } \\
\hline Number of measurements $\quad 504$ \\
\hline Median, $\mathrm{Bq} / \mathrm{m}^{3}$ & 110 \\
\hline Geometric Standard Deviation $\sigma_{g}$ & 3,1 \\
\hline
\end{tabular}

Results and discussion. FCZ analysis based on the above data was conducted separately for male and female populations for the two exposure scenarios: 11 years of schooling fell on the period of time before and after the radon-reduction activities. The evaluation results of the lifetime attributable risk are presented in Table. 2.

Assessment results of lifetime attributable risks

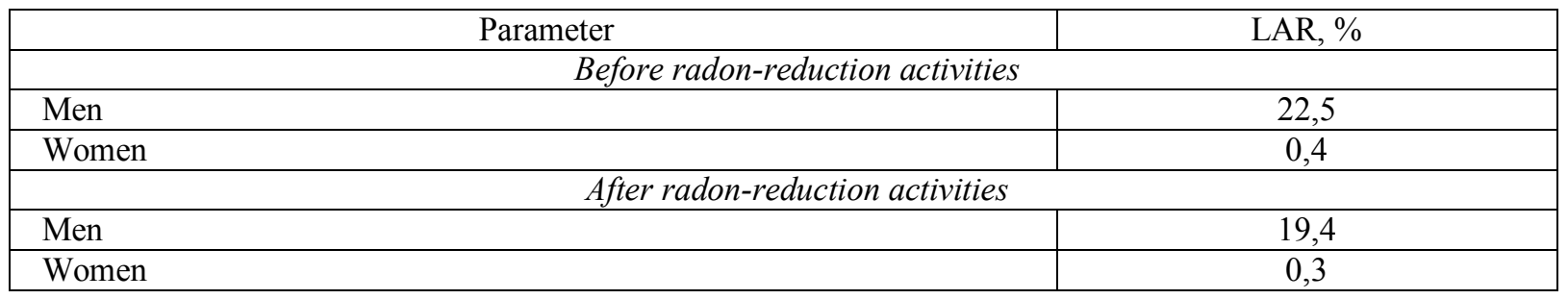

As seen from Table. 2, decreased radon EEVA (by more than half) achieved as a result of radon reduction measures led to the fact that the proportion of radon-induced deaths from lung cancer for men decreased by $3.1 \%$. For women, this effect is not so noticeable, but this is due to the significant difference in mortality from lung cancer from all causes in men and women. According to the statistics [4], among the malignant tumors in the male population of Russia, tumors of the trachea, bronchus, lung occupy the first place (19.9\% of all cases), whereas in the female population - only ten (3.9\%). Importance of the implementation of radon-reduction activities will be even more obvious if a more in-depth analysis of the scenario of exposure is conducted: before starting school, children living in Mozhaisk attend a nearby kindergarten which also reveals radon EEVA levels that exceed the established standard; the annual time children spend indoors when in kindergarten may by 2-4 times exceed the time spent on the school premises. Another important factor is reduced carcinogenic susceptibility of lung tissue with increasing attained age. In addition, a separate script should be used for the risk assessment of the school employees. 
Conclusions. Internal exposure due to inhalation of radon and its DPR is a major contributor to the individual annual effective exposure dose of the population of the Russian Federation. Identification of the population groups that live, work or study in the conditions of the radon EEVA levels that greatly exceed the established standard, and further implementation of measures aimed at normalizing the situation are important ways of ensuring the radiation safety of the population of Russia. Radon-reduction measures conducted in schools and preschools are even more important given higher carcinogenic susceptibility of the lung tissues of children compared with adults. Here, risk calculation methods are a modern tool for assessing the effectiveness of the measures, since they allow supplementing the standard evaluation of the reduction in the direct indicator of radiation safety (radon EEVA) with a long-term consequence forecast namely a decrease in the number of deaths from radon-induced lung cancer.

\section{References}

1. Balahonova A.S. Renievoe orudenenie v diktionemovyh slancah Pribaltijskogo bassejna (Leningradskaja oblast'): dis. ... kand. geol.-min. nauk [Rhenium mineralization in the Baltic Region dictyonema oil shale (Leningrad region): thesis ... cand. of Geology and Mineralogy]. St. Petersburg., 2014. 125 p.

2. Informacionnyj sbornik: «Dozy obluchenija naselenija Rossijskoj Federacii v 2012 godu» [Information collection: "Radiation doses of the population of the Russian Federation in 2012”]. St. Petersburg, 2013. 67 p.

3. Zashhita ot radona-222 $\mathrm{v}$ zhilyh zdanijah i na rabochih mestah. [Protection against radon-222 in residential buildings and workplaces]. ICRP Publication 65. Transl. from English. Moscow: Energoatomizdat, 1995. 68 p.

4. Zlokachestvennye novoobrazovanija v Rossii v 2009 godu (zabolevaemost' i smertnost') [Malignancies in Russia in 2009 (morbidity and mortality)] ed.by V.I. Chissov, V.V. Starinsky, G.V. Petrova. Moscow: FGU «MNIOI im. P.A. Gercena Minzdravsocrazvitija Rossii», 2011.260 p.

5. EMISS - Edinaja mezhvedomstvennaja informacionno-statisticheskaja sistema. Vvedena v jekspluataciju sovmestnym prikazom Minkomsvjazi Rossii i Rosstata ot 16.11.2011 g. № 318/461 [UIISS - United interagency information and statistical system. Commissioned by the joint order of the Russian Ministry of Communications and Federal State Statistics Service dated 16.11.2011, № 318/461]. Available at: http://www.fedstat.ru/ indicators/start.do.

6. Kononenko D.V.Ocenka radiacionnogo riska dlja naselenija Sankt-Peterburga pri obluchenii radonom [Evaluation of radiation risk for the population of St. Petersburg with radon exposure]. Radiacionnaja gigiena, 2013, vol. 6, no. 1, pp. 31-37.

7. Risk vozniknovenija raka legkogo pri obluchenii radonom i produktami ego raspada. Zajavlenie po radonu [Risk of lung cancer with exposure to radon and its decay products. Statement on radon]. ed. by M.V. Zhukovsky, S.M. Kiselev, A.T. Gubin. Perevod publikacii 115 MKRZ, Moscow: Izd-vo «FGBU GNC FMBC im. A.I. Burnazjana FMBA Rossii», 2013. 92 p.

8. Sanitarno-jepidemiologicheskie trebovanija $\mathrm{k}$ uslovijam i organizacii obuchenija $\mathrm{v}$ obshheobrazovatel'nyh uchrezhdenijah (SanPiN 2.4.2.2821-10) [Sanitary and epidemiological requirements for the organization and training in educational institutions (SanPiN 2.4.2.282110)]. Utv. 29.12.2010 g., vvedeny v dejstvie 01.09.2011 g. 
9. Petrova G.V., O.P. Grecova, V.V. Starinskij i dr. Harakteristika i metody rascheta statisticheskih pokazatelej, primenjaemyh $\mathrm{v}$ onkologii [Characteristics and methods of calculation of statistical indicators used in oncology]. Moscow: MNIOI im. P.A. Gercena, 2005. $39 \mathrm{p}$.

10. Krewski D., Lubin J.H., Zielinski J.M., et al. A combined analysis of North American case-control studies of residential radon and lung cancer. J. Toxicol. Environ, 2006, Health Part A 69 (7), pp. 533-597.

11. NAS (National Academy of Sciences). Health Effects of Exposure to Radon (BEIR VI). National Academy Press, Washington, D.C., 1999.

12. ICRP, 2010. Lung Cancer Risk from Radon and Progeny and Statement on Radon. ICRP Publication 115, Ann. ICRP 40 (1).

13. WHO, 1986. Indoor air quality research: Report on a WHO meeting, 27-31 August 1984, Stockholm. World Health Organization, Copenhagen, 1986.

14. Kellerer A.M. On the conversion of solid cancer excess relative risk into lifetime attributable risk. Radiat. Environ. Biophys, 2001, no. 40, pp. 249-457.

15. Grosche B., Kreuzer M., Kreisheimer M., Schnelzer M., Tschense A. Lung cancer risk among German male uranium miners: a cohort study, 1946-1998. Br. J. Cancer, 2006, no. 95, pp. 1280-1287.

16. Tomáŝek L., Rogel A., Tirmarche M., et al. Lung cancer in French and Czech Uranium Miners: Radon-Associated Risk at Low Exposure Rates and Modifying Effects of Time since Exposure and Age at Exposure. Radiat. Res., 2008, no. 169, pp. 125-137.

17. IARC, 1988. Monographs on the evaluation of carcinogenic risk to humans: Manmade fibres and radon. International Agency for Research on Cancer, Lyon, IARC 43, 1988.

18. ICRP, 1993. Protection Against Radon-222 at Home and at Work. ICRP Publication 65, Ann. ICRP 23 (2). Pergamon Press, Oxford, 1993.

19. Darby S., Hill D., Auvinen A.et al. Radon in homes and risk of lung cancer: collaborative analysis of individual data from 13 European case-control studies. Br. Med. J., 2005, vol. 330, pp. 223-227.

20. Darby S. Residential radon and lung cancer: detailed results of a collaborative analysis of individual data on 7148 subjects with lung cancer and 14208 subjects without lung cancer from 13 epidemiologic studies in Europe / S. Darby, D. Hill, H. Deo et al. Scand. J. Work Environ. Health, 2006, vol. 32 (Suppl 1), pp. 1-84.

21. Krewski D., Lubin J.H., Zielinski J.M. et al. Residential radon and risk of lung cancer. A combined analysis of 7 North American case-control studies. Epidemiology, 2005, vol. 16, pp. 137-145.

22. Lubin J.H., Wang, Z.Y., Boice Jr., J.D., et al. Risk of lung cancer and residential radon in China: pooled results of two studies. Int. J. Cancer, 2004, no. 109, pp. 132-137.

23. Tirmarche M. Quantification of Lung Cancer Risk After Low Radon Exposure and Low Exposure Rate: Synthesis from Epidemiological and Experimental Data. Final Scientific Report, February 2000 - July 2003. Contract FIGH-CT1999-0013. European Commission DG XI, Brussels, 2003.

24. Tomáŝek L., Rogel A., Tirmarche M., et al. Dose conversion of radon exposure according to new epidemiological findings. Radiat. Prot. Dosim, 2008, no. 130, pp. 98-100.

25. UNSCEAR, 2009. UNSCEAR 2006 Report, Annex E "Sources-to-effects assessment for radon in homes and workplaces". United Nations Scientific Committee on the Effects of Atomic Radiation. United Nations, New York, 2009. 